\title{
Anomalous colour in a Cuban cave-dwelling frog: First record of piebaldism in Eleutherodactylus zeus (Anura: Eleutherodactylidae)
}

\author{
L. YUSNAVIEL GARCÍA-PADRÓN ${ }^{1 *}$ \& ROBERTO ALONSO BOSCH ${ }^{2}$ \\ ${ }^{1}$ Museo de Historia Natural "Tranquilino Sandalio de Nodas". Martí 202, esquina Comandante Pinares, \\ Pinar del Río. CP. 20100, Cuba \\ 2 Museo de Historia Natural "Felipe Poey", Facultad de Biología, Universidad de La Habana, \\ Calle 25 \# 455 e/ J e I. Vedado. Plaza de la Revolución. CP10400. La Habana, Cuba \\ *Corresponding author Email: yusnaviel@gmail.com
}

\begin{abstract}
Pigmentation anomalies may occur due to genetic or environmental factors and can affect restricted parts of the body or the entire surface. Eleutherodactylus zeus is frog endemic to western Cuba where it is adapted to life in caves, rock crevices, and other sheltered sites in limestone landscapes associated with forest habitats. We observed 43 frogs in Santo Tomás cave, in Viñales National Park, of which $26 \%$ showed depigmented blotches, typical of piebaldism, along their bodies. No unusual behaviour was detected in any of these frogs. This is the first reported case of piebaldism in frogs of the West Indies and consequently of Cuba. Records of piebaldism in amphibians are very scarce in the literature, not necessarily as a consequence of its rarity in nature but possibly due to inconsistencies in the classification of pigmentation abnormalities.
\end{abstract}

\section{INTRODUCTION}

ln n spite of their largely nocturnal habits, amphibians exhibit an impressive diversity and complexity in their colour patterns (Hoffman \& Blouin, 2000). Amphibian chromatophores are located in either the epidermis or dermis, and they contain pigment granules that vary in chemical composition (e.g. carotenoids, pteridines) resulting in different colours and patterns (Bagnara et al., 1968). However, chromatic disorders occur due to genetic or environmental factors, resulting in pigmentation anomalies that are restricted to a part, or the entire, body surface. Among the main recognised types of pigmentation anomaly are albinism, axanthism, leucism and piebaldism (Bechtel, 1995; Lucati \& López-Baucells, 2016). Piebaldism is defined by Lucati \& López-Baucells (2016) as "all-white fur/skin patches and eyes normally colored". It differs from leucism where the entire body is white but the eyes are normally coloured or albinism where there is an unpigmented body with reddish or pink eyes (Lucati \& López-Baucells, 2016).

Eleutherodactylus (Syrrophus) zeus Schwartz, 1958 is a frog endemic to western Cuba. It is a cave-dwelling species adapted to life in caves, rock crevices, and other sheltered sites in limestone landscapes associated with forest habitats of the Cordillera de Guaniguanico (Alonso Bosch \& Rodríguez Gómez, 2003; Díaz \& Cádiz, 2008; Henderson \& Powell, 2009). The species has been IUCN listed as endangered because it is restricted to an area of less than $5000 \mathrm{~km}^{2}$, its distribution is severely fragmented, and there is continuing decline in the extent and quality of its habitat in western Cuba (Hedges \& Díaz, 2004). The Red Book of Cuban Vertebrates (Gonzalez et al., 2012) re-evaluated the conservation status of 61 species of amphibians in Cuba and lists 27 threatened species but failed to include $E$. zeus.
The normal colour pattern of live adults of E. zeus (Fig. 1 ) is an olive brown with a mottled black dorsum and darker brown snout. The upper eyelids of most specimens are clear green. Postscapular spots are yellowish, arms and thighs have lichenous greyish markings. Concealed surfaces of thighs are dull brownish purple, dorsum of thighs mottled brown, tips of dorsal rugosities greenish or yellowish, giving a somewhat speckled and mottled appearance (Schwartz, 1958; Estrada et al., 1986). In this report we document piebaldism in E. zeus.

\section{METHODS}

As part of monitoring initiative of E. zeus, we visited Santo Tomás cave, El Moncada, Viñales, Pinar del Río $\left(22.544496^{\circ} \mathrm{N}\right.$, $83.846895^{\circ} \mathrm{W}$, WGS 84, $230 \mathrm{~m}$ a.s.I.) in April and August of 2017. It is the only large Eleutherodactylus species present in this area, and in recent years some natural history observations on this frog have been collected by our team (Alonso Bosch et al., 2007; García, 2012; Alonso Bosch et al., 2015). The cave gallery we visited had a small entrance $(2 \mathrm{~m}$ high and $4 \mathrm{~m}$ wide) that was shaded by the forest so that only limited day light (visible to human eye) reached into the first 5 $m$ of the gallery. Observations were made from the entrance to $220 \mathrm{~m}$ inside the cave, during the day (11:00h-14:00h) and night (20:30h-01:00h), using headlamps to locate active animals. When an individual was sighted, it was collected and marked with a unique combination of toe clips (Ferner, 2009) to prevent duplicate counts and afterwards it was released where captured. We paid attention to any unusual behaviour of the animals and their general body conditions. Photo vouchers were deposited in the herpetological collections of the Museo de Historia Natural "Tranquilino Sandalio de Noda" from Pinar del Río, and Museo de Historia Natural "Felipe Poey" from University of Havana, Cuba. 




Figure 1. Colour variation in E. zeus from Santo Tomás cave, Cuba. Adult male with normal colour pattern (top left), adult female with piedbaldism in the loreal area (top right), adult female with the loreal, eyelid, dorsal head, ear and dorsal body areas affected (lower left), and adult male with dorsal and lateral body areas affected (lower right).

\section{RESULTS}

We captured a total of 56 E. zeus which amounted to 43 unique specimens after correction for repeat captures (Table 1). Eleven of these captures ( 5 adult females, 3 adult males, 2 adults of uncertain gender, and 1 juvenile) lacked normal colour patterning with depigmented blotches along their bodies (Fig. 1; Table 1). The affected individuals were observed from the entrance up to $120 \mathrm{~m}$ inside the cave. Most of the affected frogs were depigmented in more than one area, the head was the most affected area, ten frogs were depigmented in the loreal region, four frogs on the eyelids, three in the dorsal part of the head, and two in the tympanum (Fig. 1). Additionally, two frogs presented loss of pigmentation in the dorsal and lateral areas of their bodies (Fig. 1), and the fore and hind limbs of one frog were also affected. Our observations show a high rate of piebaldism with at most 11 out of 43 individuals (26\%) affected, with no obvious distinction between the sexes. However, no alteration in behaviour was detected in any of these frogs. All individuals were active during both day and night inside the cave, jumping, climbing, or vocalising. No signs of rash, itch, weight loss or fatigue were observed, all individuals were in good physical condition.

\section{DISCUSSION}

This is the first reported case of piebaldism in frogs of the West Indies and consequently of Cuba. The piebald condition has been described as an intermixture of a pattern of localised irregular patches with an absence of pigment in an otherwise normally pigmented individual (Acevedo et al., 2009). Records of piebaldism in amphibians are very scarce (Dyrkacz, 1981; Bechtel, 1995; Jablonski et al., 2014), not necessarily as a consequence of its rarity in nature but possibly due to inconsistencies in the classification of pigmentation abnormalities. Nevertheless, piebaldism has been reported in Urodela: Ambystoma mexicanum, Plethodon cinereus and Dicamptodon tenebrosus (Neff et al., 2015) and in Anura it is known from a wild population of Lithobates catesbeianus (Whipple \& Collins, 1990).

Active individuals have been sighted inside the caves during the day, while at night they usually vocalise from the ground and rocks both inside and outside caves. We found individuals of both sexes outside and inside (at different distances from the entrance) of the cave, with either normal or abnormal colour patterns. Consequently, we consider that darkness does not seem to be a determinant of the frequency 
Table 1. Number of Eleutherodactylus zeus captured, recaptured and affected by piebaldism, $M=$ males; $F=$ females, $J=j u v e n i l e, U D$ undetermined gender

\begin{tabular}{|lcccc|ccc|cccc|}
\hline & & & & \multicolumn{3}{c|}{ Recaptures } & \multicolumn{4}{c|}{ Affected } \\
\cline { 6 - 12 } & M & F & UD & J & M & F & UD & M & F & UD \\
\hline April & 17 & 10 & 0 & 8 & 0 & 0 & 0 & 2 & 3 & 0 & 1 \\
August & 8 & 9 & 2 & 2 & 6 & 6 & 1 & 1 & 2 & 2 & 0 \\
\hline
\end{tabular}

of the appearance of piebald individuals. Further studies are needed to clarify the frequency of this abnormality across western Cuba and to evaluate any biological implications that would be negative for the survival of this Cuban endemic cave-dweller.

\section{ACKNOWLEDGEMENTS}

This work was undertaken by the project "Reproductive Ecology of the Cuban Giant Frog (Eleutherodactylus zeus) in Western Cuba" supported by the Research Grant of the National Speleological Society given to the senior author. We are very thankful to Eduardo López, (former Director of the National Speleological Training Center) and his co-workers for their hospitality and logistical support. To John Fioroni, María Alejandra Pérez and Tom Kinsky for their help and donations to this study. We also thank Arturo Reyes Labrada, Shay $\mathrm{H}$. Howell, and Jeffrey S. Harrod for the very valuable help during the fieldwork and anonymous reviewers for comments on an earlier draft of the manuscript.

\section{REFERENCES}

Acevedo, J., Torres, D. \& Aguayo-Lobo, A. (2009). Rare piebald and partially leucistic Antarctic fur seals, Arctocephalus gazella, at Cape Shirreff, Livingston Island. Polar Biology 32: 41-45.

Alonso Bosch, R., \& Rodríguez, A. (2003) Insospechados habitantes de las penumbras. Pp. 26-35. In: Rodríguez- Schettino, L (Ed.) Anfibios y Reptiles de Cuba. UPC Print, Vaasa, Finland.

Alonso Bosch, R., Rodríguez, A. \& Márquez, R. (2007). Sound Guide of the Amphibians from Cuba. ALOSA sons de la natura Audio CD \& booklet, p. 46.

Alonso Bosch, R., García, L.Y., del Castillo Domínguez, S. \& Torres Martínez E.L. (2015). Clutches, nest attendance, and hatching in a rock-cave-dwelling frog, Eleutherodactylus (Syrrophus) zeus, from Cuba. Journal of Cave and Karst Studies 77: 83-86.

Bagnara, J.T., Frost, S.K. \& Matsumoto, J. (1979). On the development pigment patterns in amphibians. American Zoologist 18: 301-312.

Bechtel, H.B. (1995). Reptile and Amphibian Variants: Colors, Patterns and Scales. Krieger Publishing Co., Malabar, FL. 206 pp.

Díaz, L.M. \& Cádiz, A. (2008). Guía Taxonómica de los Anfibios de Cuba. AbcTaxa 4: 1-294.
Dyrkacz, S. (1981). Recent instances of albinismin North American amphibians and reptiles. Society for the Study of Amphibians and Reptiles. Herpetological Circular 11: 1-31.

Estrada, A.R., Novo Rodríguez, J. \& Moreno, L.V. (1986). Las ranas del grupo symingtoni, género Eleutherodactylus (Anura: Leptodactylidae) de Cuba. Poeyana 329: 1-14.

Ferner, J.W. (2009). Measuring and marking post-metamorphic amphibians. In: Amphibian Ecology and Conservation: A Handbook of Techniques. Pp. 124-141. Dodd K. C. Jr. (ed.). Oxford University Press.

García, L.Y. (2012). Eleutherodactylus zeus (Cuban Giant Frog). Record size. Herpetological Review 43: 631.

González Alonso, H., Rodríguez Schettino, L., Rodríguez, A., Mancina, C. A. \& Ramos García, I. (2012). Libro Rojo de los Vertebrados de Cuba. Pp. 304. Editorial Academia, La Habana.

Hedges, B. \& Díaz L. (2004). Eleutherodactylus zeus. The IUCN Red List of Threatened Species 2004: e.T57065A11576165. http://dx.doi.org/10.2305/IUCN. UK.2004.RLTS.T57065A11576165.en. Downloaded on 19 October 2018.

Henderson, R. W. \& Powell, R. (2009). Natural History of West Indian Reptiles and Amphibians. Pp. 495. University Press of Florida, Gainesville, Florida.

Hoffman, E.A. \& Blouin, M.S. (2000). A review of colour and pattern polymorphisms in anurans. Biological Journal of the Linnean Society 70: 633-665.

Jablonski, D., Alena, A., Vlček, P. \& Jandzik, D. (2014). Axanthism in amphibians: A review and the first record in the widespread toad of the Bufotes viridis complex (Anura: Bufonidae). Belgian Journal of Zoology 144: 93101.

Lucati, F. \& López-Baucells, A. (2016). Chromatic disorders in bats: a review of pigmentation anomalies and the misuse of terms to describe them. Mammal Review 47: 112-123.

Neff, M., Viernum, S., Twitchell, S.E. \& Mitchell, J.C. (2015). Three more unusually-colored salamanders from North America. Herpetology Notes 8: 599-601.

Schwartz, A. (1958). Another new large Eleutherodactylus (Amphibia: Leptodactylidae) from western Cuba. Proceedings of the Biological Society of Washington 71: 37-42.

Whipple, J.F., \& Collins, J.T. (1990). A unique pattern variant of the bullfrog (Rana catesbeiana). Transactions of the Kansas Academy of Science 93: 140-141.

Accepted: 12 January 2019 